\title{
Implications of development status of Korean cultural tourism for China
}

\author{
Na Wang \\ Weifang University of Science and Technology \\ Shouguang, Weifang,Shandong, 262700 China
}

\begin{abstract}
South Korea is a tourist resource-constrained country, but the development of its cultural tourism has been very successful. The article discusses the success of the development of cultural tourism in Korea, analyze China's three major development of cultural tourism comparative advantaged: cultural resources is the base, the economic strength advantage is backing, and market dominance is guaranteed. Learning from the Korean experience on the basis of the development of cultural tourism, our country should let the government be the engine, take the idea of boutique development, noting that the development of cultural tourism should focus on ethnic cultural awareness, training people especially the younger generation of cultural self-confidence.
\end{abstract}

Keywords- Cultural tourism, development experience, Korea, comparative advantage, cultural consciousness

\section{INTRODUCTION}

South Korea's land area is just over 90,000 square km, tourism resources are very limited. But South Korea can take advantage of the limited tourism resources, and find out traditional culture resources, so that tourism and the unique Korean national culture can be combined together, perfecting each tourism projects, making the production of a batch of cultural tourism products with high added value. Such as the World Intangible Cultural Heritage "Gangneung Dano Festival" Spring ritual and Jeju Folk Village, and the United States "Hollywood" Indian "Bollywood" comparable "Hallyuwood" Cultural Park and Seoul MBC "Dae Jang Imamura, "etc., they can be called the Korea culture and Tourism boutique, attracting many foreign tourists into Korea. Even in 2008, under the background of global financial crisis, the ROK still inbound tourists reached $6,890,841$ people, more than in 2007 but an increase of $6.9 \%$. According to the Forecast of Korea Tourism Organization on May 19: 2010 China is expected to surpass Japan to become the largest source country of tourism in Korea, In addition to the RMB appreciation and simplified facilitation, the main reason for the increase in Chinese tourists travel to Korea, we can still see that the "Korean wave" has a profound impact on Chinese residents, Korean cultural tourism products and its derivatives are still a major motivation for Chinese citizens attracted by South Korea. Therefore, the successful experience of Korean cultural tourism will provide a reference to develop our own distinctive cultural tourism.

\section{SUCCESSFUL EXPERIENCE OF THE DEVELOPMENT OF KOREAN CULTURAL TOURISM}

\section{A. Government Support}

To take "take advantage of cultural enjoyment, through cultural integration, with the cultural development of the Republic of Korea" as a slogan, Korea established the Korea Culture and Tourism Ministry and the dissemination of culture by strengthening overseas to improve South Korea's national brand, enhance the country's image. South Korean Ministry of Culture and Tourism website offers translations in 10 languages, to facilitate international visitors to view. The site details the travel (transportation, lodging, shopping), culture and art, food, tourism and other celebrations throughout South Korea, which greatly facilitates the tourists to Korea, and through a photo exhibition, video player, etc. to attract more the visitors to travel. The South Korean government on cultural tourism provides a stable financial support, the Ministry of Culture and Tourism of Korea accounted for $1 \%$ of the annual budget of the country's total budget dedicated to improving the quality of Korean culture and tourism products, and expanding the influence of Korean cultural tourism in the world.

\section{B. Fine tourism products}

South Korea's land area is small, less historical sites, but South Korea focus on "fine" tourism products to enhance the attractiveness and influence their tourism resources. Whether the design of tourist attractions or development of tourist goods, South Korea are actively making efforts to take effective measures to maximize the added value, For example: South Korea's largest island - Jeju Island, an area of 1846 square kilometers, only $5 \%$ of Hainan Island area. However, this area of the island, has contributed immeasurably to South Korea's economic growth. According to Yonhap statistics, by the end of 2011, the number of foreign tourists to Jeju reached 100 million, of which China accounted for half of tourists; tourism revenue created by foreigners was up to 60 billion yuan.

Before undeveloped, Jeju Island is actually a fishing village, after the development, the local Jeju retained some of the original buildings, it will be transformed into folk village, restore the original appearance of the village, the people's shabby houses, shops and so on. Everyday there are wonderful programs at a fix time in the open air such as: folk 
dance, acrobatics and rural primary drumming. This folk village vividly reappear the culture and lifestyle of the people at that time, so that tourists can also increase cultural and historical understanding of Korea during recreation.

Travel to Korea, one should buy souvenirs. South Korean tourist souvenirs have strong ethnic characteristics, carrying the traditional Korean culture and ethnic customs. The traditional Korean culture integrated into souvenir design, coupled with the wealth of creativity in order to produce a souvenir to meet customer needs, these souvenirs from design to color, from process to packaging are pursuing excellence. Korean souvenirs are not only for profits, but also to shoulder the heritage of national culture, to show the charm of Korea through memorabilia to more people.

South Korean tourist in terms of publicity, the greatest success is more than delicately transplanted the tourist attractions in the drama. South Korea's many attractions is through drama, this important influence in the formation of carrier worldwide. As a result of "Dae Jang Geum" fame folk village; little known Ushijima is well known by the movie "Mermaid"; the Lotte playground, carousel, etc. in Stairway to Heaven ".Compared to South Korea, the country's tourist attractions, tourism resources are more abundant, there are some influence at home and abroad to produce classic film work, however, the success of the classic examples of creating video works by tourist attractions are not many, tourist attractions in our country should be increasingly implanted in the film and television work, in order to achieve a win-win for maximum effect.

\section{CHINESE COMPARATIVE ADVANTAGE OF DEVELOPING CULTURAL TOURISM}

Comparative advantage is relative to the absolute advantage, it's not a competitive advantage which can play a crucial role in winning or losing, but if comparative advantages into full play, and its energy is also not to be underestimated. China's cultural tourism, economic, market and resource development has its own comparative advantage, facing and rationally using these comparative advantages, can better develop its own distinctive cultural tourism.

\section{A. Base: cultural resources}

Cultural resources are the base of the development of cultural tourism. "The number of World Heritage" is one of the key advantages of China in 2009 global competitiveness rankings of travel. According to "Tourism Competitiveness Report 2009" shows that China ranked No. 3 in the world in terms of the number of World Heritage. China has many world-class cultural heritage: As of August 2010, China has 25 cultural heritage, 4 natural and cultural heritage sites and the two cultural landscapes included in the "World Heritage List", coupled with China's long history and civilization heritage, paved Chinese culture rich cultural heritage, which is the most obvious comparative advantage of our development of cultural tourism. When combined with the cultural and creative industries assistance, the objective of deep, large-scale development of cultural tourism can be achieved.

\section{B. Backing: Economic strength advantage}

Cultural tourism is a high investment high return tourism projects. Generally rich cultural heritage of the region has comparative advantage in the development of cultural tourism. But if there are no culture deposits, cultural creative projects can also engage in cultural tourism, so the key is the cultural project with economic support. In China, the typical example of the creative elements combined with a model of cultural tourism is Le Palace in Xian, from 1998 to 2008, Le Palais totally received more than 5.2 million visitors from around the world, including European and American tourists accounted for $58 \%$, but it is inseparable from heavily economic support. With the rapid economic development of our country, now we have the economic ability to support the development of cultural tourism, but also more people have the ability to consume cultural tourism, it is our most reliable comparative advantage of the development of cultural tourism.

\section{Warranty: market advantage}

From the view of tourism revenue, the main tourist market refers to inbound tourism market and the domestic tourism market. According to the United Nations World Tourism Organization forecasts that by 2020, China will become the world's largest country and the fourth largest tourist source country, we cannot clearly separate overseas markets is whether this huge cultural tourism consumers, but as long as we cultural tourism products are featured and attractive, the market is cultural tourism consumer market. In addition, most of the younger generation have only one child, they have the ability to conditionally consumer culture tourism, which is a market cannot be ignored. Consumer can experience our national culture in tourism, accept the influence of traditional culture in a relaxed environment, feel g modern creative culture; this is a matter of concern in the future market.

\section{IMPLICATIONS OF THE DEVELOPMENT OF KOREAN CULTURAL TOURISM FOR CHINA}

\section{A. Focus on product innovation and the atmosphere innovation in the process of the development of cultural tourism in the city}

In the development of cultural tourism, Korea attaches great importance to the process of product innovation. They think that only a good product can attract discerning and discerning cultural tourists. The city's traditional creative cultural products, services and heritage and media, entertainment, design, architecture, fashion and other creative industries combine to provide innovative products to tourists, as well as the concomitant of an open and tolerant environment, not only ability to attract and create classes, also attract tourists. Simple products have rich cultural connotations and innovative industry is not enough, tolerance and diversity is a critical success factor. For tourists, the destination is not just a place, but a state, resident lifestyle, customs and traditions, cuisine and language which are more attractive. 


\section{B. Focus on ethnic and cultural diversity}

Korea in the development of cultural tourism, paid great attention to ethnic and cultural diversity, the ethnic and cultural diversity as an important resource, the purpose to explore these features is to defend local products, so that cultural tourism products and traditions rooted in local culture, so that a region or city can have more features.

\section{Focus on the cultural design of the city image}

Relations in Korea urban design and urban image of cultural tourism are getting closer. Whether it is a unique city or urban image of cultural tourism products are designed to be very valued. In some cities, noted the importance of urban tourism image, but for the urban cultural tourism image of work there is a great distance.

\section{Emphasis on the development of festivals and events, while focusing on cooperation and coordination between the cities}

Cultural festivals and events are seen as an important part of cultural tourism marketing. Usually fleeting events, Festivals can only be held at a specific date. These constitute an important reason to attract tourists to come to travel. Festivals and events can make the status of the destination in the minds of tourists to greatly improve, is an important means of attracting tourists. However, the increasing scale of festivals and events, increasing investment, whether it is a good urban infrastructure and new urban culture festival, has a huge budget. And we almost did not notice the cooperation and coordination between the major events of the city, it is necessary to learn in China's development of the city cultural tourism.

\section{E. Using the Internet to disseminate and update information}

Disseminate and update information on the Internet has played a good role, compared with printed promotional materials, information on the Internet are more timely. Surveys show that long-distance travelers are more willing to use the Internet for the information of destination, which is worth learning and thinking for us.

\section{F. Using city card offers benefits and convenience for urban cultural tourists}

Korean culture tourists' travel offers convenience and benefits for tourists through the practice of issuing city card. Our country can learn from this approach when conditions are permitted.

\section{G. Focus on authenticity of visitors' feeling}

South Korean city managers have recognized: With the accelerated process of globalization, the spread of mass products in the world, authenticity in terms of attracting tourists is playing an increasingly important role. Urban cultural tourists is seeking authenticity which refers not only what to see, but also requires their experience is real, and over-crowded will damage the real experience for tourists.

\section{CONCLUSION}

Urban cultural tourism is a complex, urban cultural tourism market is constantly changing. In the process of development of cultural tourism in the city, we should continue to study the market, understand the market, draw on the experience of Korean culture and tourism development, study the tourist motivation, behavior deeply, and based on the needs to contribute to the cooperation between city to city, state to state, the mainland and the mainland, and to make the development of cultural tourism in our cities healthy and sustainable.

\section{REFERENCES}

[1] Huangxiu Lin .Korean culture and tourism development experience and Enlightenment to China[J]. Economic Issues,2011,03:124-127.

[2] Yin Yue. Draw on the successful development of cultural tourism in Korea to China $[\mathrm{J}]$. Chifeng College (Natural Science Edition),2012,15:116-117.

[3] Li Dandan. Successful experience Korean culture industry trade Research and Enlightenment [D] to China. Hebei University of Economics, 2013.

[4] Liyi Hui. Korean cultural tourism festivals Policy Analysis and Implications [J]. Theory Monthly,2013,07:181-184.

[5] Jin Li, Zhao Liming. Development of cultural tourism in European cities and Enlightenment to China [J]. Productivity,2007,12:82-83. 